\title{
Archaeology and rapid climate changes: from the collapse concept to a panarchy interpretative model
}

\author{
Mihael Budja \\ Department of Archaeology, Faculty of Arts, University of Ljubljana, SI \\ miha.budja@ff.uni-lj.si
}

\begin{abstract}
The 'rapid climate change', 'cycles of abrupt climate shift', and 'cold events' in the Holocene are discussed in relation to the 'collapse of civilisation' concept, and adaptive cycles and the panarchy interpretative model.
\end{abstract}

IZVLEČEK - V članku predstavljamo 'hitre klimatske spremembe', 'cikle nenadnih klimatskih premen' in 'hladne dogodke'v povezavi s konceptom 'kolapsa civilizacij', adaptivnimi cikli in interpretativnim modelom 'panarhije'.

KEY WORDS - archaeology; rapid climate changes; collapse; resilience; sustainability; adaptive cycles; panarchy

\section{Introduction}

The first interpretations linking climate change to the trajectories of civilisation and culture appeared at the beginning of the $20^{\text {th }}$ century, and were embedded in geographical, climatological and archaeological studies. Sudden droughts and aridification were recognised as climatic and environmental determinants related to catastrophic scenarios and the collapse of civilisations in Egypt, Mesopotamia, and India, as well as nomadic tribes from Central Asia invading Europe (Huntigton 1926; Brooks 1926). In a parallel adaptive scenario within the context of cultural evolution, the 'oasis theory' determined the development of subsistence strategies, including the cultivation of plants and domestication of animals, and the introduction of farming (Childe 1928).

By the end of the $20^{\text {th }}$ century, climatologists had introduced a model of long-term global and regional dynamics of climate changes at 3000-year intervals within the period $18000 \mathrm{BP}$ and the present, which was embedded in the Cooperative Holocene Mapping Project (COHMAP). The model simulation was based on well-dated radiocarbon biological and geological proxy data, such as pollen in lake sediments, lake levels, marine plankton, ice sheet dimensions and sea-ice extent. They suggested that the driving forces behind many long-term climatic changes were the varying insolation in the upper atmosphere and dynamics in global atmospheric circulation (COHMAP Members 1988). They correlated the first climate change in the Holocene within the interval between 13000 in $10000 \mathrm{BP}$ with the Neolithic revolution in the Near East. Transition to farming was marked in this context as an "early human response to a unique sequence of climatic events" (Wright 1993.466).

\section{Rapid climate changes}

The model of long-term climate changes was soon replaced by Bond's 'cycle of abrupt climate shifts', 'rapid climate changes' (RCC) and 'cooling events'. The first was introduced by Gerard Bond et al. (1997; 1999) and linked to eight 'Ice Rafting Detritus' (IRD) phases in the North Atlantic in a cycle of $\sim 1470 \pm$ 500 years. In deep core drillings, these phases are marked by the accumulation of eight layers of icerafted lithic debris, primarily caused by iceberg discharges from the northern ice-shield. Ice-rafting episodes were associated with ocean surface cooling, each case of which appears to have been caused by a rather substantial change in the North Atlantic thermohaline circulation. The eight IRD events were 
dated by planktonic foraminifera AMS ${ }^{14} \mathrm{C}$ dating in two deep-sea drilling cores, and embedded in the following sequence: 11.3, 10.3, 9.5, 8.2, 5.9, 4.3, 2.8 and 1.4 years calBP (Bond et al. 1997.Fig. 2). It was suggested that increased inflows of glacial water in the correlate with the periods of reduced solar activity (Bond et al. 2001; Barber et al. 2004). However, Bond's annual cycle has not been confirmed in either the Eastern or Western Mediterranean; intervals of $\sim 2300$ to 2500 years were suggested for the former (Rohling et al. 2002b), and 1300, 1515, 2000, and 5000 years for the latter (Rodrigo-Gámiz 2014). The cooling events in the Eastern Mediterranean have been associated with reductions in solar output and in stratospheric ozone production, which led to cooling of the lower stratosphere and later to the changed meridional extent of atmospheric cells. These were ascribed to an intensification and increased frequency of wintertime northerly outbreaks of cold polar and continental air over the basin in the periods 8.6-8.0, 6.0-5.2, 4.2-4.0 and 3.1-2.9 calBP. Contemporaneous cooling events have been identified in the Adriatic Sea (Rohling et al. 2002a; Siani et al. 2013).

The rapid climate changes (RCC) model was introduced by Paul A. Mayewski $e t$ al. (2004). They identified as many as six RCC periods for the Holocene in a cycles of $\sim 2800-2000$ and 1500 years. RCC are given as 9000-8000, 6000-5000, 4200-3800, 3500$2500,1200-1000$, and $600-150$ calBP years (Fig. 1). These periods were documented by a comparison of $\sim 50$ globally distributed palaeoclimate records, carefully selected according to length (full Holocene coverage), sampling resolution (dating resolution better than 500 years), interpretation quality, and geographic distribution. The first rapid climate change, well known as the ' $8.2 \mathrm{ka}$ calBP event', relates to the process of Neolithisation in Europe. It was caused by a strong, cold fresh-water pulse from the Laurentide Lakes in North America into the North Atlantic. The others relate to variations in solar radiation output. The cooling of the Northern Hemisphere, droughts in the tropics and changes in atmospheric circulation are characteristics of all rapid climate changes. A contrasting pattern is documented at the mid-latitudes $43^{\circ}$ and $50^{\circ} \mathrm{N}$ in the French Pre-Alps, on the Swiss Plateau, and in Central Europe. Pollen records, palaeohydrological and other proxy data in lake sediments during the first RCC point to an evidently wet period. Lake level fluctuations show a sequence of lake level maxima, preceded and followed by lake level minima (Magny et al. 2003). A similar tripartite sequence has been recorded in the Central and
Western Mediterranean within the 4.2ka calBP event. Wet periods and high lake levels at $c$. 4300-4100 and 3950-3850 years calBP were interrupted by a dry period with low lake levels between $c$. 41003950 years calBP (Magny et al. 2009; 2012).

The concept of centennial-scale 'cold events' relates to Bond's cycles model. It was grounded on analyses of temperature, precipitation and glacier dynamics proxy data that are preserved in various terrestrial, lake and deep-water sediment and ice-core palaeoclimatic archives. Heinz Wanner et al. $(2008 ; 2011)$ thus identified six cold events in the Holocene. The first, the $8.2 \mathrm{ka}$ BP cold event, was embedded in the period 8300-8100 calBP. It should be stressed, however, that cooling anomalies in different regions are given in a longer period of 4 to 6 centuries ( $R o h$ ling, Pälike 2005). The first was followed by the 6.55.9, 4.8-4.5 and 3.3-2.5 events at c. 6400-6200, $4800-4600$ in $2800-2600$ calBP. The latest two, the fifth (1.75-1.35) and the sixth (0.7-0.15) cold events date to the periods between $500-300$ and $650-450$ calBP (300-600 and 1200-1800 AD). These are associated with the Dark Ages, the Migration Period, and the Little Ice Age (Wanner et al. 2011).

The fifteen episodes of high lake levels parallel the rapid climate changes and cold events. These were documented in 26 lakes in the foothills of the Western Alps, the Jura Mountains and in the central plateau in Switzerland. The episodes are radiocarbon dated and embedded in the following calendar sequences: $11250-11050,10300-10000,9550-9150$, 8300-8050, 7550-7250, 6350-5900, 5650-5200, 4850-4800, 4150-3950, 3500-3100, 2750-2350, 1800-1700, 1300-1100, and 750-650 calBP (Magny 2004).

South of this area, in the Central Mediterranean, wet periods occurred in the time intervals $c .10200$, $9300,8200,7300,6200,5700-5300,4800,4400$ $3800,3300,2700-2300,1700,1200$ and 300 calBP. In the Middle Holocene, a trend of a contrasting pattern of the precipitation regime can be observed. Wet winters and dry summers are documented above $40^{\circ} \mathrm{N}$, and wet winters and wet summers in the southern regions. This pattern reversed in the Late Holocene (Magny et al. 2012; 2013; Peyron et al. 2013).

In archaeology, associations between prehistoric cultures and climate changes were determined by various theoretical concepts and interpretative contexts (Trigger 1971; 1996). They were embedded in the 
deterministic model of unilineal cultural evolution and diffusion. This model postulates that every change in human behaviour patterns, in the progress of economy and technology, as well as cultural trajectories was directly connected to climate and environmental changes (Clark 1936; Childe 1958). A similar concept was introduced by new or processual archaeology, whereby the evolution of prehistoric societies was determined by a successful cultural adaption to climate and environmental change (Binford 1968; Tainter 1988). In post-processual archaeology, the opposite was proposed: all changes in past societies, even in the natural environment, were triggered by human agency (Hodder 1986; Tilley 1994).

In parallel interdisciplinary studies, the landscape dynamics and cultural transformations in the Holocene have always been directly related to climate and environmental fluctuations at the regional and global level (for an overview, see Berglund 2003; Brown, Bailey, Passmore 2015). The correlation was based on the radiocarbon dates both of archaeological contexts and glaciological (ice cores), geological and geochemical (terrestrial and marine) and biotic palaeoclimate archives. The most important proxy data on past climates and climate events are: oxygen and carbon isotopic composition, trace element and micro-particle concentrations, gas content in air bubbles; glacial deposits and features of glacial erosion, periglacial features, lacustrine sediments, and erosional features, relict soils and volcano eruptions; biochemical markers in fossil plant and animal planktic, oxygen and carbon isotopic composition in ocean deposits and sapropel deposits; pollen and plant macrofossils in lake and terrestrial sediments, diatoms, ostracods, and insects in lake sediments; stable oxygen $(\delta 180)$ and carbon $\left(\delta^{13} \mathrm{C}\right)$ isotopes in speleothems; tree ring width, density and carbon stable isotope composition, stable carbon isotope in barley grains (Bradley 1999; Briffa 2000; Sach et al. 2000; Barber et al. 2004; Rudiman 2008; Marino et al. 2009; Steinhilber et al. 2012; Wanner et al. 2012; Riehl et al. 2014; Magny et al. 2004).

The first comprehensive connection between rapid climate changes, past cultural dynamics, and archaeological cultures on a global scale was embedded in the paleoclimatic interpretative context. It was based on a statistical analysis of the distribution of 815 radiocarbon dates connected to fluctuations in the pollen sequence, the rise in sea levels, and the pre- 
sence of peat in palaeobotanical data, as well as on 3700 dates connected to 155 archaeological cultural sequences (Wendland, Bryson 1974).

The continuing catastrophic explanations present rapid climate changes as the cause, and the collapse of population and civilisation as well as the 'Dark Ages' as its effects. The collapse of cultures such as the Mycenae in Greece, the Hittite and Akkadian empires, and the $3^{\text {rd }}$ dynasty in Ur in Mesopotamia, and dynastic periods V and VI in Egypt were all linked to rapid climate changes (Carpenter 1966; Bell 1971; Bryson et al. 1974; deMenocal 2001). All these events have been connected with sudden cooling events and dry periods, and the desertification of these regions. These interpretations were legitimised by Barbara Bell's postulate that climate fluctuations present a historical reality as much as the 'Dark Ages' (Bell 1971.2). Great emphasis was placed on the so-called 'Tell Leilan event', a disruption in the settlement of many tell sites in northern Mesopotamia (i.e. Tell Leilan, Tell Brak, Tepe Gawra) around 2200 calBC that marks the rapid climate change and desertification of the region, the collapse of the irrigation system and of the Akkadian Empire (Weiss et al. 1993; Courty, Weiss 1997; Weiss, Bradley 2001; Cullen et al. 2000; deMenocal 2001). A similar scenario was proposed for the fall of Mayan civilisation (Hodell et al. 1995; deMenocal 2001; Haug et al. 2003). Karl W. Butzer indicated the conceptual weakness and interpretative limitations of deterministic models (Butzer 1972; 1975; 2012; Butzer, Endfield 2012). He offered an alternative, cultural ecology approach to the concepts of climate fluctuation and the hypothesis of climate as the only cause of social collapse. Butzer emphasises that the activities of past pre-industrial societies destroyed the balance in regional ecosystems and caused shifts in subsistence, population, and culture that did not result in the collapse of systems, but in cultural and economic adaptations to new environments and a changed climate. A similar concept was introduced by the French Annales School, where historians emphasised that the influence of climate change on past societies was only indirect and barely visible. As an example, they referred to the Little Ice Age and the plague outbreak at the end of the $16^{\text {th }}$ in addition to the general crisis in the $17^{\text {th }}$ century in Europe. However, Le Roy Ladurie (1971. 17) suggested that famine, pandemics, migrations, low food production and its high cost, as well as lack of money "are not and cannot be facts which are strictly climatic". Crawford S. Holling (1973) introduced the concept of 'resilience' into ecological studies, in which he stressed that natural systems have a capacity to absorb environmental and climate changes without dramatically altering. But resilience has its limitations, and as the changes reach a critical limit, the system then changes and adapts to another condition.

\section{Change in paradigms}

The climatologist Wallace S. Broecker already warned in the 1970s of an "inevitable global warming" (Broecker 1975), and the oceanographer John Imbrie of the possibility that the use of fossil fuels would push our planet into a "super-interglacial age, unlike anything experienced in the last million years" (Imbrie, Imbrie 1979.185).

The global warming scenario became increasingly popular after the first assessment report on the climate system and its estimated changes in the future which was published in 1990 by the Intergovernmental Panel on Climate Change (IPCC) at the UN. The substitution of the rapid global cooling paradigm with the paradigm on global warming was based on new proxy data on the correlation between past gas concentrations in the atmosphere and climate changes in ice-core and deep-water paleoclimate archives, the use of climate models such as the atmospheric and oceanic general circulation model (GCM), and the rise of global temperatures in the last century (Chambers, Brain 2002; Alley et al. 2003). In the fourth assessment report, which comprised progress reports by three different working groups (the second group focused on the environmental impact and human adaptability to climate change) it was stated that the increasing greenhouse gas emissions since 1750 were the result of human activities. Carbon dioxide $\left(\mathrm{CO}_{2}\right)$ and methane $\left(\mathrm{CH}_{4}\right)$ concentrations are higher now than at any time in the past 650000 years. The same applies to nitrous oxide $\left(\mathrm{N}_{2} \mathrm{O}\right)$ concentrations in the past 16000 years (Bernstein et al. 2008; Parry et al. 2007). The documented increase in carbon dioxide and methane concentration levels in the time span between 6000 and $3000 \mathrm{BC}$ could be connected with the beginning of agriculture and deforestation in Europe and to rice cultivation, rice fields and irrigation systems in India and China (Ruddiman 2003).

Concerns due to the human influence on current global warming and the rapid reinforcement of assessments on the frequency, rapidity and volume of climate changes in the past have encouraged a series of reflections on past environmental disasters and 
the human response to them. In this context, the catastrophic approach and the collapse concepts as single-cause interpretative hypotheses became increasingly popular. These hypotheses linked sudden cooling and droughts in the past with the collapse of ancient civilisations: the Akkadian Empire in Mesopotamia, the Old Kingdom in Egypt, the pre-Columbian American civilisations, the Mayan and Moche civilisations in Mesoamerica and South America, as well as the Norse culture in Greenland (Arneborg et al. 1999; Cullen et al. 2000; Gill 2000; deMenocal, 2001; Van Buren 2001; Hassan 2001; Hodell et al. 2001; 2005; Williams 2002; Haug et al. 2003; Stanley et al. 2003; Dillehay et al. 2004; Fagan 2004; Diamond 2005; Rodning 2010). Jared Diamond $(2005.3,6,20)$ was the only one of these authors who cautioned on the complexity of the processes and the often ignored fact that these past shifts in civilisation (e.g., population decline and/or reduction of political, economic and social complexity on a larger scale over a long period) were not necessarily real ecological collapses, but collapses induced by unsustainable subsistence strategies, poor natural resource management, and the degradation of ecosystems.

\section{The concept of adaptive strategies}

Collapse is seen as the most radical adaptation strategy of past societies to climate change (Tainter 2000a.332). Colin Renfrew (1979a; 1979b) has defined collapse with the help of system theory and catastrophe theory as an allactic type of cultural change defined by two development trajectories, the anastrophic and the catastrophic. Anastrophe denotes the rise in organisational complexity and centralisation, as well as the emergence of new bureaucratic and other authoritative structures, resulting in an increase in the use of economic resources. Catastrophe denotes the fall of centralised and socially structured complex societies and their regressive transformation into fragmentary and dissociated chiefdoms and tribal communities. In both trajectories, the bifurcation point presents key elements; these are division points in which a system takes its own trajectory, which is always limited by old systemic political, economic, technological postulates and values. Bifurcation points are also destabilisation points, where even the smallest internal and/ or external causes (climate change, political and economic shifts, war, and migration) can effect huge, although gradual, changes. Collapse is therefore a transformation trajectory that can take centuries and leads back to less structured and poorly con- nected tribal communities. Renfrew predicted that in marginal areas, some old social structures survived and triggered the process of renewed transformation into complex and centralised communities.

Additionally, Joseph A. Tainter (1988) defined the collapse of complex prehistoric and historical societies as a political process in which a society displays a rapid, i.e. in a few decades, loss of an established level of socio-political complexity, whereby a society either collapses or enters into a new development cycle. Similarly to Renfrew, he anticipated that this process is connected to the economic effect of marginal returns and the operation of social elites, which in the short term may facilitate a successful adaptation to the changed natural environment by means of transformed economic strategies and the intensive use of natural resources. Next, due to erroneous economic policies and the overdevelopment of social structures, the process causes social collapse (Tainter 2006a). Tainter based his ideas on James G. Miller's (1978) general theory of living systems that are organised into interactive sub-systems, on their interaction, influence and attitude to the environment. The premise underlying this theory is that nature presents a continuum of complex life action organised into various patterns that are repeated at all system levels. Nevertheless, Tainter (2006b) noted a key difference between the two theories. The relationship of environmental conditions to human sustainability is indirect and subtle. The relationship is mediated by human capacities in problem solving. Sustainability is not the achievement of stasis; it is not a passive consequence of having fewer humans consuming more limited resources: one must work at sustainability. The challenges to sustainability that any society (or other institution) might confront are, for practical purposes, endless in number and infinite in variety. This being so, sustainability is a matter of problem solving, an activity so commonplace that we perform it with little reflection. Rarely does science address the issue of problem solving, or its long-term consequences.

Complexity, according to Tainter (200b), is therefore an economic category and a basic problemsolving tool. Complexity is generally understood to refer to such things as the size of a society, the number and distinctiveness of its parts, the variety of specialised social roles that it incorporates, the number of distinct social personalities present, and the variety of mechanisms for organising these into a coherent, functioning whole (Tainter 2006b.92; 
1988. 23). We define sustainability as maintaining, or fostering the development of systemic contexts that produce goods, services and amenities that people need or value at an acceptable cost for as long as they are needed or valued (Allen, Tainter, Hockstra 2003.26).

According to the diminishing return and marginal productivity theories introduced by the neo-classical school of economics, problems can only be addressed successfully within a given time. Namely, the cost of problem management can eventually reach a point where continual investments in complexity will not be correspondingly profitable. Higher input costs usually result in lower profits. When they reach marginal productivity, any further investment in complexity contributes less to general productivity than the previous investment. After an extended period of diminishing returns, problem solving becomes ineffective and sustainability unstable, and societies become vulnerable. Problem-solving trajectories can continue for decades, generations or centuries; the results are: collapse, adaptation and recovery with a lower level of complexity, the maintenance of sustainability with increased levels of complexity and the exploitation of alternative resources. Sustainable development is therefore the ability of a society to maintain a continuing action of political and social structures, their hierarchy and permanent accessibility to economic resources (Tainter $2006 \mathrm{~b}$. 92; 2014.202). Tainter cited the collapse of the Akkadian Empire, the fall of the Roman Empire and Mayan civilisation on the one hand, and the recovery of the Byzantine Empire and colonial Europe on the other.

The interpretative estimate of sustainability is resilience in certain conditions. Although, Timothy F. $\mathrm{H}$. Allen et al. (2003.26) cautioned that it is important to distinguish sustainability from resilience. Sustainability is the capacity to continue a desired condition or process, social or ecological. Resilience is the ability of a system to adjust its configuration and functioning despite disturbance. In social systems, resilience can mean abandoning sustainability goals and the values that underlie them. Sustainability and resilience can conflict.

On the other hand, Fikret Berkes et al. $(2003.2,6)$ obscured the distinction between sustainability and resilience. They described sustainability as a dynamic process and the adaptive capacity of societies to adjust to any given climate and environmental condition. At the same time, sustainability is the protective capacity of ecosystems to support social and economic systems. They linked resilience to the capacity to adapt to changes in terms of growth and renewal cycles.

As already stated, the concept of resilience was introduced to ecology by Holling in the early 1980s. He later connected resilience with the adaptive cycle (Holling 1986) and with the hierarchy of social-ecological systems, and termed this 'panarchy' (Holling, Gunderson 2000; Holling 2001; Holling, Gunderson, Ludwig 2002.5) ${ }^{1}$. He conceptualised it as the continuum of hierarchical cross-scale dynamics and the intertwined set of adaptive and renewal cycles that define the sustainability of social-ecological systems (Holling 2001.396; Gunderson et al. 2002). In other words, panarchy is a hierarchical structure in which systems of nature and humans, as well as combined human-nature systems and social-ecological systems are interlinked in unending adaptive cycles of growth, accumulation, restructuring, and renewal (Gunderson et al. 1995; Folke et al. 1998). The size of this structure in social contexts ranges from a household to an empire.

Panarchy is the recurrent adaptive cycle of four phases of processes and events. The first phase, the ' $r$ ' phase, is associated with exploitation, fast migration to uninhabited or sparsely inhabited areas, rapid population growth, new technologies, and subsistence strategies. The second, the ' $\mathrm{K}$ ' phase, is associated with a static period, mismanagement, and increasing rigidity. The third, the ' $\Omega$ ' phase, is the period of creative destruction and chaotic problem solving, the abandonment of economic resources, collapse and migrations. The fourth and final phase, the ' $\alpha$ ' phase, is a period of reorganisation and renewal (Gunderson et al. 2002; Berkes et al. 2003; Walker, Salt 2006.163; Folke 2006; Scheffer 2009; Aimers, Iannone 2014). Due to sudden, unpredicted and long-term events and processes formed outside these cycles, especially in the adaptive phase, the total collapse of panarchy and permanent disruption of the continuum of system functions are possible. Holling (2001.399) linked the collapse to long-term and catastrophic events.

\footnotetext{
1 Panarchy is coined from two words, pan-hierarchy, and denotes the correlation between change and sustainability, between the predictable and unpredictable. Crawford S. Holling, Lance H. Gunderson and and Donald Ludwig (2002.5) combined the name of the Greek god Pan (change and unpredictability) and the term hierarchy to denominate structures that maintain the system and allow for progress. In should be stated that philosophers have used the term since 1591. Panarchy is also included in system theory as the opposite of hierarchy.
} 
Panarchy is therefore a model of the reorganisation of hierarchical structures into dynamic adaptive entities, sensitive to even small disruptions in the transition from the growth phase to the 'omega' collapse and reorganisation phase, as well as in the transition from the 'alpha' phase of fast growth. Special emphasis is placed on the importance of inter-level dynamics and interactions that lead from revolt to creative destruction and to the activation of memory. This directs both reorganisation and renewal. Memory is the accumulated experience and history of the system, providing context and sources for renewal, recombination, innovation, novelty and self-organisation following disruption (Holling 2001; Gunderson et al. 2002.16). In other words, social memory refers to the long-term communal understanding of the dynamics of environmental change and the transmission of the pertinent experience, as used, for example, in the context of climate change (McIntosh 2000.24). Panarchy is therefore both creative and conservative, maintaining the dynamic balance between rapid changes and traditions on the one hand, and interactive inter-level dynamics on the other. The system is maintained and advanced simultaneously (Holling 2001). Resilience is therefore the ability to constantly reorganise existing social structures, hierarchies and economic practices and to start the growth cycle again and again. In other words, resilience is the ability to maintain sustainable development (Smit, Wandel 2006).

Historical geographers and paleoecologists have placed collapse in scenarios of trajectories of vulnerability and environment-culture interactions. They maintain that the collapse of past civilisations is the direct consequence of climate change, and refer to various economic-development and population models based on the evolution paradigm of a gradual,

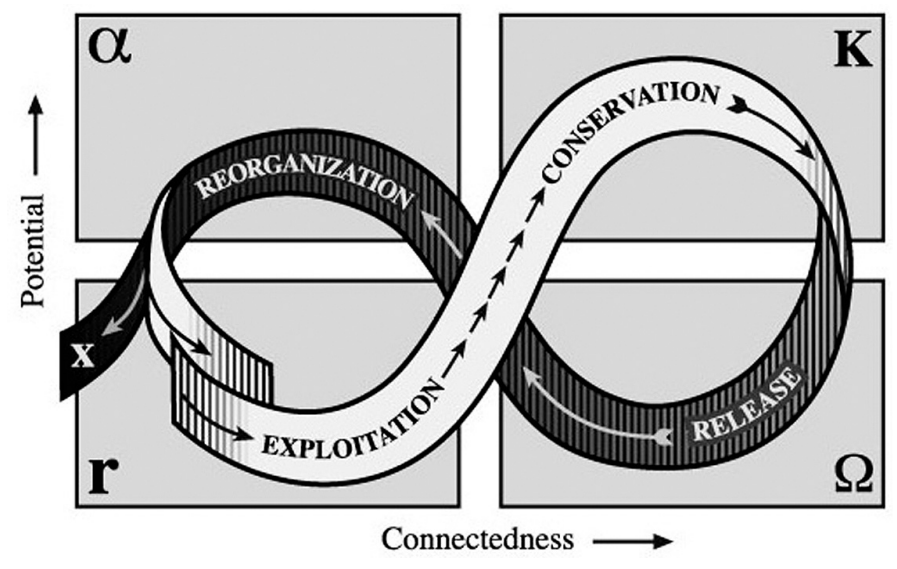

Fig. 2. Holling's continuum of adaptive cycles (after Holling, Gunderson 2002.Fig. 2-1). continuous and unilineal growth of past societies. At first, highly vulnerable Mesolithic hunter-gatherers and Neolithic farmers were placed in the trajectory of vulnerability. These are followed by less vulnerable complex and centralised as well as highly productive and stable agrarian-urban societies, although these societies may again become vulnerable in overpopulated areas and in areas where the exploitation of natural resources is uncontrolled. In the first group, the collapse of the whole culturaldemographic system is the only response to climate events. Only the second group has integrated adaptation practices, and it is connected to the beginning of the agricultural revolution at the end of the $18^{\text {th }}$ century (Messerli et al. 2000). In the context of complex environment-culture interactions, four different responses of past societies to climate and environmental changes are presented (Coombes, Barber 2005). The first response is the total collapse of population in remote areas due to the loss of the means of subsistence, the rapid decline of the economy, and shifts below the subsistence level. The second response is partial decline in population in remote areas due to the food supply being above the subsistence level. In the third, climate and environmental changes set off technological progress and changes in food production which support new social-economic developments and the formation of new levels of social complexity. This scenario is based on a model of economic development by Ester Boserup $(1965 ; 1988)$ according to which past societies were forced to reform and update their subsistence practices due to population growth and limited natural resources (intensive use and/or loss of subsistence resources due to climate anomalies). The fourth response proposed a general collapse of social structures in the main regions as well as in remote areas. This is based on the scenario of cascade collapse in self-organising systems of complex past societies, which includes key concepts such as fractals and self-organised criticality used in theoretical physics. In our case, this is simply the repeated pattern of critical events in a natural setting, in politics, the economy, and social relations (Brunk 2002). Any of these can cause the gradual collapse of a social system. Therefore, Paul Combes and Keith Barber (2005. 309) estimated that a general collapse of a self-organising system can be the direct consequence of any type of critical event. They agree that the collapse of Mesopotamian and Mesoamerican civilisations were caused by rapid climate change and the subsequent global cooling periods and droughts. 
RCC and collapses or adaptions of prehistoric cultures

The main focus in paleoclimatology and prehistoric archaeology was on the first cooling period and the 8.2 climate event, as well as on paleoclimatic records in the Eastern Mediterranean and western part of the Near East, southern Balkans, and on the Apennine Peninsula (Rohling, Pälike 2005; Rohling et al. 2009; Pross et al. 2009; Dormoy et al. 2009; Peyron et al. 2011; Tubi, Dayan 2013; Magny et al. 2013; Magny, Combourieu Nebout 2013; Francke et al. 2013; Siani et al. 2013). The event was dated from Greenland ice cores to $8300+10 /-40$ and 8140 +50/-10 calBP (Rasmussen et al. 2014).

Two scenarios were proposed for the early Neolithic evolution in the Near East and Europe in correlation with the $8.2 \mathrm{BP}$ climate event. The first states that rapid cooling events and droughts caused a cultural, economic, and population collapse, the abandonment of settlements in the Levant, south-western Anatolia (Catalhüyük) and on Cyprus, as well as the migration of farmers and herders into Southeast Europe (Clare et al. 2008; Weninger et al. 2009; 2014; Özdoğan 2014). The second scenario suggested that the abandonment of settlements and a gap in population density were minor and documented at only a few (4 to 83) Neolithic sites. Farmers and herders developed new social and subsistence adaptation strategies and did not migrate to distant locations in Southeast Europe (Flohr et al. 2015; see also Budja 2007 ). Both scenarios are based on a significant number of archaeological sites and radiocarbon dates. The first includes 42 sites and 735 radiocarbon dates (Weninger et al. 2014), and the second includes 83 sites and 3397 radiocarbon dates (Flohr et al. 2015).

Similarly, Bond's fifth, 5.9 IRD event is connected to the cultural, economic, and population collapse of the first farming communities (early Neolithic Linear Pottery Culture) in Central and Western Europe (Shennan, Edinborough 2007) on the one hand. On the other, the resilience and adaptive cycles theory revealed that RCC did not have an immediate and catastrophic impact. Climate change was only one of the destabilising elements. Periods of drought and changed precipitation cycles therefore coincide with population decline and changed settlement patterns (reduction in settlement size and smaller number of houses). Periods with high rainfall coincide with population growth. Periods of peak climate oscillations (5140/30 and 5090/80 denBC) in which dry periods alternate with abnormally wet periods and periods of unusually high temperatures (5106/05 denBC) are connected to the construction of defensive walls around settlements, social conflict and violence in eastern regions, while in western regions the greatest population density can be observed in periods of high rainfall after 5098 denBC. Cultural shifts and population collapse happened only after the documented climate anomalies (Gronenborn et al. 2014).

Mayewski's RCC periods of 6000-5200 and 3000$2930 \mathrm{BP}$ were suggested to correlate with the collapse of Copper and Bronze Age cultures (the abandonment of Troy VIIb9) in Southeast Europe and parts of Anatolia (Weninger 2009.48-49). In contrast, the end of the Bronze Age culture in Ireland is radiocarbon dated after the RCC period and correlates to economic and social collapse caused by a shift to new technologies, namely, iron metallurgy and the formation of new economies and social networks (Armit et al. 2014).

In Mesopotamia, these RCC periods are connected with the loss of monsoon rains, to droughts and cooling events. The first RCC period affected the collapse of Uruk culture in Mesopotamia, and two centuries later, the end of the Jemdet Nasr period ( $\mathrm{BrO}^{-}$ oks 2006; 2011; 2013). In the central Sahara, an evident decline in the herding economy and transhumance lifestyle occurred. The population structure disintegrated, since the number of sites above latitude $23^{\circ} \mathrm{N}$ was significantly reduced; population densities remained high only at oases (di Lernia 2002; Vernet, Faure 2000).

In Central China, along the Yellow River and in Inner Mongolia, these RCC periods are associated with a set of rapid and strong cooling periods and changes in the East-Asian monsoon cycle, as well as the collapse of farmer-herder cultures such as Liangzhu, Shijiahe, Shangdong Longshan, and Laohushan (Zhang et al. 2000; Wu, Liu 2004; Xiao et al. 2004).

Recently, attempts to conceptualise the archaeology of climate change can be observed on the theoretical level. These are based on the well-known premise that climate and environmental changes were not the only changes faced by past societies and can therefore not be used as a default to explain their collapse. Great emphasis is placed on regional ecological variability and the economic, social, and emotional responses of past societies. These are recognised in changed subsistence strategies and the formation of ritual landscapes or loci (van de Noort 
2011a; 2011b). In contrast, Toby Pillatt (2012) suggests a research and interpretative retreat from climate and society. In his opinion, the key elements are weather, landscape, and social memory. He recognises weather as a material condition of the landscape, and landscape as a material manifestation of human-environment relations. Social memory is seen as a way of bridging the long-term processes of climate change and the immediate decisions made by people in the past in response to the weather. This functioned as the conceptual and symbolic basis that enabled the transfer of environmental behaviour from generation to generation. Actions at a particular point in history are dependent on perceptions of the environment as they are filtered through the collective knowledge of past experiences stored as social memory. The link with the resilience model described above is evident.

\section{References}

Aimers J., Iannone G. The Dynamics of Ancient Maya Developmental History. In G. Ianonne (ed.), The Great Maya Droughts in Cultural Context. Case Studies in Resilience and Vulnerability. University Press of Colorado. Boulder: 21-50.

Allen T. F. H., Tainter J. A. and Hoekstra T. W. 2003. Supply-Side Sustainability. Columbia University Press. New York.

Alley R. B., Marotzke J., Nordhaus W. D., Overpeck J. T., Peteet D. M., Pielke R. A., Pierrehumbert R. T., Rhines P. B., Stocker T. F., Talley L. D. and Wallace J. M. 2003. Abrupt Climate Change. Science 299: 2005-2010.

Armit I., Swindles G. T., Becker K., Plunkett G. and Blaauwd M. 2014. Rapid climate change did not cause population collapse at the end of the European Bronze Age. Proceedings of the National Academy of Sciences of the United States of America 111(48): 17045-17049.

Arneborg T. W., Heinemeier J., Lynnerup N., Nielsen H. L., Rud N. and Sveinbjornadottir A. E. 1999. Change of diet of the Greenland Vikings determined from stable isotope analysis and ${ }^{14} \mathrm{C}$ dating of their bones. Radiocarbon 41 : 157-168.

Barber K. E., Chambers F. M. and Maddy D. 2004. Late Holocene climatic history of northern Germany and Denmark: peat macrofossil investigations at Dosenmoor, SchleswigHolstein, and Svanemose, Jutland. Boreas 33: 132-144.

Berkes F., Colding J. and Folke C. 2003. Introduction. In F. Berkes, J. Colding and C. Folke (eds.), Navigating Social-Ecological Systems. Building Resilience for Complexity and Change. Cambridge University Press. Cambridge: $1-30$.

Bell B. 1971. The Dark Ages in Ancient History. I. The First Dark Age in Egypt. American Journal of Archaeology 75 (1): 1-26.
Berglund B. E. 2003. Human impact and climate changes synchronous events and acausal link? Quaternary International 105: 7-12.

Bernstein L. and 39 authors (eds.) 2008. Climate Change 2007. Synthesis Report. Intergovernmental Panel on Climate Change. World Meteorological Organization. Geneve.

Binford L. R. 1968. Archaeological perspectives. In S. R. Binford, L. R. Binford (eds.), New perspectives in archaeology. Aldine. Chicago: 5-32.

Bond G., Showers W., Cheseby M., Lotti R., Almasi P., de Menocal P., Priore P., Cullen H., Hajdas I. and Bonani G. 1997. A pervasive millennial-scale cycle in the North Atlantic Holocene and glacial climates. Science 29: 1257-1265.

Bond G. C., Shower W., Elliot M., Evans M., Lotti R., Hajdas I., Beosnan G. and Johnso S. 1999. The North Atlantic's 1-2 kyr Climate Rhythm' Relation to Heinrich Events, Dansgaard/Oeschger Ceycles and the Little Ice Age. In P. U. Clark, R. S. Webb and L. D. Keigwin (eds.), Mechanisms of Global Climate Change at Millennial Time Scales. Geophysical Monograph Series. American Geophysical Union. Washington, DC: 35-58.

Bond G., Kromer B., Beer J., Muscheler R., Evans M. N., Showers W., Hoffmann S., Lotti-Bond R., Hajdas I. and Bonani G. 2001. Persistent solar influence on North Atlantic climate during the Holocene. Science 278: 1257-1266.

Boserup E. 1965. The conditions of agricultural growth: the economics of agrarian change under population pressure. Allen and Unwin. London.

1988. Environment, Population, and Technology in Primitive Societies. In D. Worster (ed.), The Ends of the Earth. Cambridge University Press. Cambridge: 23-38.

Bradley R. S. 1999. Paleoclimatology. Reconstructing Climates of the Quaternary. Academic Press. San Diego. 
Briffa K. R. 2000. Annual climate variability in the Holocene: interpreting the message of ancient trees. Quaternary Science Reviews 19: 87-105.

Brown T., Bailey G. and Passmore D. 2015. Environments and landscape change. In J. Harding, C. Fowler and D. Hofmann (eds.), Oxford Handbook of Neolithic Europe. Oxford University Press. Oxford: 27-61.

Broecker W. S. 1975. Climate change: are we on the brink of a pronounced global warming? Science 189: 460-463.

Brooks C. E. P. 1926. Climate through the ages. A study of the climatic factors and their variations. R. V. Coleman. New York. H. \& J. Pillans \& Wilson Printers. Edinburgh.

Brooks N. 2006. Cultural responses to aridity in the Middle Holocene and increased social complexity. Quaternary International 151: 29-49.

2011. Human Responses to Climatically-driven Landscape Change and Resource Scarcity: Learning from the Past and Planning for the Future. In I. P. Martini and W. Chesworth (eds.), Landscapes and Societies. Selected Cases. Springer. New York: 43-66.

2013. Beyond collapse: climate change and causality during the Middle Holocene Climatic Transition, 64005000 years before present. Geografisk Tidsskrift-Danish Journal of Geography 112(2): 93-104.

Brunk G. G. 2002. Why do Societies Collapse? A Theory Based on Self-Organized Criticality. Journal of Theoretical Politics 14(2): 195-230.

Bryson R. A., Lamb H. H. and Donley D. L.1974. Drought and the decline of Mycenae. Antiquity 48(189): 46-50.

Budja M. 2007. The 8200 calBP 'climate event' and the process of neolithisation in south-eastern Europe. Documenta Praehistorica 34: 191-201.

Butzer K. W. 1972. Environment and archaeology. Methuen. London.

1975. The Ecological Approach to Archaeology: Are We Really Trying? American Antiquity 40(1): 106-111.

2012. Collapse, environment, and society. Proceedings of the National Academy of Sciences of the United States of America 109(10): 3632-3639.

Butzer K. W., Endfieldb G. H. 2012. Critical perspectives on historical collapse. Proceedings of the National Academy of Sciences of the United States of America 109 (10): 3628-3631.
Carpenter R. 1966. Discontinuity in Greek Civilization. Cambridge University Press. Cambridge.

Chambers F. M., Brain S. A. 2002. Paradigm shifts in late Holocene climatology? The Holocene 12: 239-249.

Childe V. G. 1928. The most ancient East: the oriental prelude to European prehistory. Kegan Paul. London.

1958. Retrospect. Antiquity 32: 69-74.

Clare L., Rohling E. J., Weninger B. and Hilpert J. 2008. Warfare in Late Neolithic/Early Chalcolithic Pisidia, southwestern Turkey. Climate induced social unrest in the late 7th millennium calBC. Documenta Praehistorica 35: 65-92.

Clark J. G. D. 1936. The Mesolithic settlement of northern Europe. Cambridge University Press. Cambridge.

COHMAP Members. I988. Climatic Changes of the Last 18,000 Years: Observations and Models Simulations. Science 241(4869): 1043-1052.

Coombes P., Barber K. 2005. Environmental determinism in Holocene research: causality or coincidence? Area 37 (3): 303-311.

Courty M. A., Weiss H. 1997. The scenario of environmental degradation in the Tell Leilan region, NE Syria, during the late third millennium abrupt climatic change. In H. N. Dalfes, G. Kukla and H. Weiss (eds.), Third Millennium BC Climatic Change and Old World Collapse. Springer. Berlin: 107-148.

Cullen H. M., deMenocal P. B., Hemming S., Hemming G., Brown F. H., Guilderson T. and Sirocko F. 2000. Climate change and the collapse of the Akkadian empire: Evidence from the deep sea. Area 4: 379-382.

deMenocal P. B. 2001. Cultural responses to climate change during the late Holocene. Science 292(5517): 667-673.

Diamond J. 2005. Collapse. How Societies Choose to Fail or Succeed. Penguin Books. London.

Dillehay T., Kolata A. L. and Mario Pino Q. 2004. Pre-industrial human and environment interactions in northern Peru during the late Holocene. The Holocene 14: 272281.

di Lernia S. 2002. Dry climatic events and cultural trajectories: Adjusting Middle Holocene pastoral economy of the Libyan Sahara. In F. A. Hassan (ed.), Droughts, food and culture: Ecological change and food security in Africa's Later Prehistory. Kluwer. New York: 225-250. 
Dormoy I., Peyron 0., Combourieu-Nebout N., Goring S., Kotthoff U., Magny M. and Pross J. 2009. Terrestrial climate variability and seasonality changes in the Mediterranean region between 15000 and 4000 years deduced from marine pollen records. Climate of the Past 5: 615-632.

Fagan B. 2004. The Long Summer. How Climate Changed Civilization. Granta Books. London.

Flohr P., Fleitmann D., Matthews R, Matthews W. and Black S. 2015. Evidence of resilience to past climate change in Southwest Asia: Early farming communities and the 9.2 and 8.2 ka events. Quaternary Science Reviews: http://dx.doi.org/10.1016/j.quascirev.2015.06.022

Folke C. 2006. Resilience: The emergence of a perspective for social-ecological systems analyses. Global Environmental Change 16: 253-267.

Folke C., Berkes F. and Colding J. 1998. Ecological practices and social mechanisms for building resilience and sustainability. In F. Berkes, C. Folke (eds.), Linking social and ecological systems. Cambridge University Press. London: 414-436.

Francke A., Wagner B., Leng M. J. and Rethemeyer J. 2013. A Late Glacial to Holocene record of environmental change from Lake Dojran (Macedonia, Greece). Climate of the Past 9: 481-498.

Gill R. B. 2000. The Great Maya Droughts. Water, Life, and Death. University of New Mexico Press. Albuquerque.

Gronenborn D., Strien H.-C., Dietrich S. and Sirocko F. 2014. 'Adaptive cycles' and climate fluctuations: a case study from Linear Pottery Culture in western Central Europe. Journal of Archaeological Science 51: 73-83.

Gunderson L. H., Holling C. S. and Light S. S. 1995. Barriers and bridges to the renewal of ecosystems and institutions. Columbia University Press. New York.

Gunderson L. H., Holling C. S., Pritchard L. Jr. and Peterson G. D. 2002. Resilience of Large-Scale Resource Systems. In L. H. Gunderson, L. Pritchard (eds.), Resilience and the behavior of large-scale systems. Scientific Committee on Problems of the Environment (SCOPE) Series, Book 60. Island Press. Washington: 3-19.

Hassan F. A. 2001. The collapse of the old kingdom: low floods, famines and anarchy. In Y. Yasuda, J. S. Kharakwal, H. Ogasawara and K. Gotanda (eds.), Environmental Changes and Rise and Fall of Civilizations. Abstracts of Third Workshop of the ALDP, 5-9 November, 2001. Japan. Monsoon 3 Kyoto and Mikata: 39.
Haug G. H., Günther D., Peterson L. C., Sigman D. M., Hughen K. A. and Aeschlimann B. 2003. Climate and the Collapse of Maya Civilization. Science 299: 1731-1734.

Hodell D. A., Curtis J. H. and Brenner M. 1995. Possible role of climate in the collapse of Classic Maya civilization. Nature 375: 391- 394.

Hodell D. A., Brenner M., Curtis J. H. and Guilderson T. 2001. Solar forcing of drought frequency in the Maya lowlands. Science 292: 1367-1369.

Hodell D. A., Brenner M. and Curtis J. H. 2005. Terminal Classic drought in the northern Maya lowlands inferred from multiple sediment cores in Lake Chichancanab (Mexico). Quaternary Science Reviews 24: 1413-1427.

Hodder I. 1986. Reading the past: current approaches to interpretation in archaeology. Cambridge University Press. Cambridge.

Holling C. S. 1973. Resilience and Stability of Ecological Systems. Annual Review of Ecology and Systematics 4: $1-23$.

1986. Resilience of ecosystems; local surprise and global change. In W. C. Clark, R. E. Munn (eds.), Sustainable development of the biosphere. Cambridge University Press. Cambridge: 292-317.

2001. Understanding the Complexity of Economic, Ecological, and Social Systems. Ecosystems 4: 390-405.

Holling C. S., Gunderson L. H. 2002. Resilience and Adaptive Cycles. In L. H. Gunderson, C. S. Holling (eds.), Panarchy. Understanding Transformations in Human and Natural Systems. Island Press. Washington, Covelo, London: 25-61.

Holling C. S., Gunderson L. H. and Ludwig D. 2002. In Quest of a Theory of Adaptive Change. In L. H. Gunderson, C. S. Holling (eds.), Panarchy. Understanding Transformations in Human and Natural Systems. Island Press. Washington, Covelo, London: 3-21.

Huntington E., Simpson G. C. 1926. The Pulse of Progress: Including a Sketch of Jewish History. Charles Schribner's Sons. New York. London.

Imbrie J., Imbrie K. P. 1979. Ice ages: solving the mystery. Macmillan. London.

Le Roy Ladurie E. 1971. Times of Feast, Times of Famine. A History of Climate Since the Year 1000. Doubleday. Garden City. New Jork. 
Magny M., Bégeot C., Guiotb J. and Peyron 0. 2003. Contrasting patterns of hydrological changes in Europe in response to Holocene climate cooling phases. Quaternary Science Reviews 22: 1589-1596.

Magny M. 2004. Holocene climate variability as reflected by mid-European lake-level fluctuations and its probable impact on prehistoric human settlements. Quaternary International 113(1): 65-79.

Magny M., Vannière B., Zanchetta G., Fouache E., Touchais G., Petrika L., Coussot C., Walter-Simonnet, A. V. and Arnaud F. 2009. Possible complexity of the climatic event around 4300-3800 cal BP in the central and western Mediterranean. The Holocene 19: 823-833.

Magny M., Peyron 0., Sadori L., Ortu E., Zanchetta G., Vannière $\mathrm{B}$. and Tinner, W. 2012. Contrasting patterns of precipitation seasonality during the Holocene in the southand northcentral Mediterranean. Journal of Quaternary Sciences 27: 494-502.

Magny M. and 34 coauthors. 2013. North-south palaeohydrological contrasts in the central Mediterranean during the Holocene: tentative synthesis and working hypotheses. Climate of the Past 9: 2043-2071.

Magny M., Combourieu Nebout N. 2013. Holocene changes in environment and climate in the central Mediterranean as reflected by lake and marine records. Climate of the Past 9: 1447-1454.

Marino G., Rohling E. J., Sangiorgi F., Hayes A., Casford J. L., Lotter A. F., Kucera M. and Brinkhuis H. 2009. Early and middle Holocene in the Aegean Sea: interplay between high and low latitude climate variability. Quaternary Science Reviews 28: 3246-3262.

Messerli B., Grosjean M., Hofer T., Núñez L. and Pfister C. 2000. From nature-dominated to human-dominated environmental changes. Quaternary Science Reviews 19: 459-479.

Mayewski P. A., Rohling E. E., Stager J. C., Karlén W., Maasch K. A., Meeker L. D., Meyerson E. A., Gasse F., Van Kreveld S., Holmgren K., Lee-Thorp J., Rosqvist G., Rack F., Staubwasser M., Schneider R. R. and Steig E. J. 2004. Holocene climate variability. Quaternary Research 62(3): 243-255.

McIntosh R. J., Tainter J. A. and McIntosh S. K. 2000. Climate, History, and Human Action. In R. J. McIntosh, J. A. Tainter and K. S. McIntosh (eds.), The Way the Wind Blows. Climate, History, and Human Action. Columbia University Press. New York: 1-42.

Miller J. G. 1978. Living Systems. McGraw-Hill. New York.
Özdogan M. 2014. A new look at the introduction of the Neolithic way of life in Southeastern Europe. Changing paradigms of the expansion of the Neolithic way of life. Documenta Praehistorica 41: 33-50.

Parry M., Canziani 0. and Palutikof J. (eds.) 2007. Climate Change 2007: Impacts, Adaptation and Vulnerability. Contribution of Working Group II to the Fourth Assessment Report of the Intergovernmental Panel on Climate Change. Intergovernmental Panel on Climate Change. Cambridge University Press. Cambridge, New York..., Delhi.

Peyron 0., Goring S., Dormoy I., Kotthoff U., Pross J., de Beaulieu J.-L., Drescher-Schneider R., Vannière B. and Magny M. 2011. Holocene seasonality changes in the central Mediterranean region reconstructed from the pollen sequences of Lake Accesa (Italy) and Tenaghi Philippon (Greece). The Holocene 21(1): 131-146.

Peyron 0., Magny M., Goring S., Joannin S., de Beaulieu J.L., Brugiapaglia E., Sadori L., Garfi G., Kouli K., Ioakim C. and Combourieu-Nebout N. 2013. Contrasting patterns of climatic changes during the Holocene across the Italian Peninsula reconstructed from pollen data. Climate of the Past 9: 1233-1252.

Pillat T. 2012. From climate and society to weather and landscape. Archaeological Dialogues 19(1): 29-42.

Pross J., Kotthoff U., Müller U. C., Peyron O., Dormoy I., Schmiedl G., Kalaitzidis S. and Smith A. M. 2009. Massive Perturbation in Terrestrial Ecosystems of the Eastern Mediterranean Region Associated with the $8.2 \mathrm{Kyr}$ BP Climatic Event. Geology 37(10): 887-890.

Rasmussen S. 0. and 23 coauthors. 2014. A stratigraphic framework for abrupt climatic changes during the Last Glacial period based on three synchronized Greenland ice-core records: refining and extending the INTIMATE event stratigraphy. Quaternary Science Reviews 106 : $14-28$.

Renfrew C. 1979a. Systems collapse as social transformation: catastrophe and anastrophe in early state societies. In C. Renfrew, K. L. Cooke (eds.), Transformations: mathematical approaches to culture change. Academic Press. New York: 481-506.

1979b. Transformations. In C. Renfrew, K. L. Cooke (eds.), Transformations: mathematical approaches to culture change. Academic Press. New York: 3-44.

Riehl S., Pustovoytov K. E., Weippert H., Klett S. and Hole F. 2014. Drought stress variability in ancient Near Eastern agricultural systems evidenced by $\delta^{13} \mathrm{C}$ in barley grain. Proceedings of the National Academy of Sciences of the United States of America 111(34): 12348-12353. 
Rodrigo-Gámiz M., Martínez-Ruiz F., Rodríguez-Tovar F. J., Jiménez-Espejo F. J. and Pardo-Igúzquiza E. 2014. Millennial- to centennial-scale climate periodicities and forcing mechanisms in the westernmost Mediterranean for the past 20,000 y.r. Quaternary Research 81: 78-93.

Rodning C. 2010. Place, Landscape, and Environment: Anthropological Archaeology in 2009. American Anthropologist 112(2): 180-190.

Rohling E. J., Casford J., Abu-Zied R., Cooke S., Mercone D., Thomson J., Croudace I., Jorissen F. J., Brinkhuis H., Kallmeyer J. and Wefer G. 2002a. Rapid Holocene climate changes in the eastern Mediterranean. In F. Hassan (ed.), Droughts, Food and Culture. Ecological Change and Food Security in Africa's Later Prehistory. Kluwer Academic/Plenum Publishers, New York: 35-46.

Rohling E. J., Mayewski P. A., Abu-Zied R. H., Casford J. S. L. and Hayes A. 2002b. Holocene atmosphere-ocean interactions: records from Greenland and the Aegean Sea. Climate Dynamics 18: 587-593.

Rohling E., Pälike H. 2005. Centennial-scale climate cooling with a sudden cold event around 8,200 years ago. $\mathrm{Na}$ ture 434: 975-979.

Rohling E. J., Hayes A., Mayewski P. A. and Kucera M. 2009. Holocene Climate Variability in the Eastern Mediterranean, and the End of the Bronze Age. In C. Bachhuber, R. G. Roberts (eds.), Forces of Transformation. The End of the Bronze Age in the Mediterranean. Proceedings of an international symposium held at St. John's College, University of Oxford 25-6th March 2006. Themes from the Ancient Near East BANEA Publication Series, Vol. 1. Oxford: $2-5$.

Ruddiman W. F. 2003. The Anthropogenic Greenhouse Era Began Thousands of Years Ago. Climatic Change 61(3): 261-293.

Ruddiman W. F. 2008. Earth's Climate. Past and Future. W. H. Freeman and Company. New York.

Sach J. P., Schneider R. R., Eglinton T. I., Freeman K. H., Ganssen G., McManus J. J. and Oppo D. W. 2000. Alkenones as paleoceanographic proxies. Geochemistry Geophysics Geosystem G3 1: 2000 GC000059.

Scheffer M. 2009. Critical transitions in nature and society. Princeton University Press. Cambridge.

Siani G., Magny M., Paterne M., Debret M. and Fontugne M. 2013. Paleohydrology reconstruction and Holocene climate variability in the South Adriatic Sea. Climate of the Past 9: 499-515.
Shennan S., Edinborough K. 2007. Prehistoric population history: from the Late Glacial to the Late Neolithic in Central and Northern Europe. Journal of Archaeological Science 34: 1339-1345.

Smit B., Wandel J. 2006. Adaptation, adaptive capacity and vulnerability. Global Environmental Change 16(3): 282292.

Steinhilber F., Abreu J. A., Beer J., Brunner I., Chrisl M., Fischer H., Heikkilä U., Kubik P. W., Mann M., McCracken K. G., Miller H., Miyahara H., Oerter H. and Wilhelms F. 2012. 9,400 years of cosmic radiation and solar activity from ice cores and tree rings. Proceedings of the National Academy of Sciences of the United States of America 109(16): 5967-5971.

Stanley J.-D., Krom M. D., Cliff R. A. and Woodward J. C. 2003. Short contribution: Nile flow failure at the end of the Old Kingdom, Egypt: Strontium isotopic and petrologic evidence. Geoarchaeology 18: 395-402.

Tainter J. A. 1988. The Collapse of Complex Societies. New studies in Archaeology. Cambridge University Press. Cambridge.

2000a. Global change, history, and sustainability. In R. J. McIntosh, J. A. Tainter and K. S. McIntosh (eds.), The Way the Wind Blows. Climate, History, and Human Action. Columbia University Press. New York: 331-356.

2000b. Problem Solving: Complexity, History, Sustainability. Population and Environment 22(1): 3-41.

2006a. Archaeology of Overshoot and Collapse. $A n$ nual Review of Anthropology 35: 59-74.

2006b. Social complexity and sustainability. Ecological complexity 3: 91-103.

2014. Collapse and Sustainability: Rome, the Maya, and the Modern World. Archeological Papers of The American Anthropological Association 24: 201-214.

Tilley C. 1994. A phenomenology of landscape: places, paths and monuments. Berg. London.

Trigger B. 1971. Archaeology and Ecology. World Archaeo$\operatorname{logy} 2(3)$ : 321-336.

1996. A history of archaeological thought. Cambridge University Press. Cambridge.

Tubi A., Dayan U. 2013. The Siberian High: Teleconnections, Extremes and Association with the Icelandic Low. International Journal of Climatology 33(6): 1357-1366. 
Van Buren M. 2001. The archaeology of El Niño events and other 'natural' disasters. Journal of Archaeological Theory and Method 8: 129-149.

Van de Noort R. 2011a. Conceptualising climate change archaeology. Antiquity 85: 1039-1048.

2011b. North Sea archaeologies; a maritime biography $10000 B C-A D$ 1500. Oxford University Press. Oxford.

Vernet R., Faure H. 2000. Isotopic chronology of the Sahara and the Sahel during the late Pleistocene and the early and Mid-Holocene (15,000-6000 BP). Quaternary International 68-71: 385-387.

Walker B., Salt D. 206. Resilience Thinking Sustaining Ecosystems and People in a Changing World. Island Press. Washington.

Wanner H., Beer J., Bütikofer J., Crowley T. J., Cubasch U., Flückiger J., Goosse H., Grosjean M., Joos F., Kaplan J. O., Küttel M., Müller S. A., Prentice I. C., Solomina O., Stocker T. F., Tarasov P., Wagner M., Widmann M. 2008. Mid- to Late Holocene climate change: an overview. Quaternary Science Reviews 27: 1791-1828.

Wanner H., Solomina 0., Grosjean M., Ritz S. P. and Jetel M. 2011. Structure and origin of Holocene cold events. Quaternary Science Reviews 30: 3109-3123.

Wanner H. and 27 coauthors. 2012. 9,400 years of cosmic radiation and solar activity from ice cores and tree rings. Proceedings of the National Academy of Sciences of the United States of America 109(16): 5967-5971.

Wendland W. M., Bryson R. A. 1974. Dating climatic episodes of the Holocene. Quaternary Research 4(1): 9-24.

Weiss H., Courty M.-A., Wetterstrom W., Guichard F., Senior L., Meadow R. and Curnow A. 1993. The Genesis and Collapse of Third Millennium North Mesopotamian Civilization. Science NS 261(5124): 995-1004.
Weiss H., Bradley R. S. 2001. What Drives Societal Collapse? Science 291: 609-610.

Weninger B., Clare L., Rohling E. J., Bar-Yosef 0., Böhner U., Budja M., Bundschuh M., Feurdean A., Gebel H.-G., Jöris O., Linstädter J., Mayewski P., Mühlenbruch T., Reingruber A., Rollefson G., Schyle D., Thissen L., Todorova H. and Zielhofer C. 2009. The Impact of Rapid Climate Change on Prehistoric Societies during the Holocene in the Eastern Mediterranean. Documenta Praehistorica 36: 7-59.

Weninger B., Clare L., Gerritsen F., Horejs B., Krauß R., Linstädter J., Özbal R. and Rohling E. J. 2014. Neolithisation of the Aegean and Southeast Europe during the 6600-6000 calBC period of Rapid Climate Change. Documenta Praehistorica 41: 1-31.

Williams P. R. 2002. Rethinking disaster-induced collapse in the decline of the Andean highland states: Wari and Tiwanaku. World Archaeology 33: 361-374.

Wright H. E. 1993. Environmental Determinism in Near Eastern Prehistory. Current Anthropology 34(4): 458469.

Wu W., Liu T. 2004. Possible role of the "Holocene Event 3 " on the collapse of Neolithic Cultures around the Central Plain of China. Quaternary International 117: 153166.

Zhang H. C., Ma Y. Z., Wünnemann B. and Pachur H.-J. 2000. A Holocene climatic record from arid northwest China. Palaeogeography, Palaeoclimatology, Palaeoeco$\log y$ 162: 389-401.

Xiao J., Xu Q., Nakamura T., Yang X., Liang W. and Inouchi Y. 2004. Holocene vegetation variation in the Daihai Lake region of northcentral China: A direct indication of the Asian monsoon climatic history. Quaternary Science Reviews 23: 1669-1679. 